UDC 351

DOI: https://doi.org/10.26642/jen-2019-2(88)-69-75

M.V. Skyba, PhD in Public Administration, Assistant Professor

Kyiv National University of Technologies and Design,

\title{
Main directions for improvement of education policy tools in the context of sustainable economic development
}

\begin{abstract}
The article generalizes the arguments and counterarguments within the scientific discussion of education policy. The purpose of the article is to present trends in the development of educational institutions, the analysis of the main aspects of the situation in education and the development of recommendations for improving the management and quality of education. The systematization of literary sources and approaches to solving the problem of education management proves that education becomes important in terms of the formation and creative potential and development of innovation human potential. The material is presented in the following logical sequence: the characteristic features of the state of education are determined, tendencies are clarified, problems are identified, and recommendations are proposed. The methodical tools of the research became general scientific and special methods of scientific research. The object of the research is the process of education policy in Ukraine. The situation of the education in Ukraine is characterized by the imperfection of the institutional environment and steady trend towards reducing the number of educational institutions, pre-school educational institutions, general educational institutions, vocational schools, and higher educational institutions. The author proposes some recommendations, which can improve education policy in the context of sustainable economic development. The implementation of recommendations makes it possible to improve the management and quality of education, creates conditions to increase innovation potential, and quality of human and intellectual capital. The results of the research can be useful for scientific and educational institutions, and experts.
\end{abstract}

Keywords: human capital, educational policy, management, education system, school, university.

Introduction. World development report 2019: states that education is one of the building blocks of human capital. Kim (2018) argues that even though human capital is the principal driver of sustainable growth and poverty reduction, policy makers sometimes find it hard to make the case for human capital investments. In addition, the benefits of investing in people can take a long time to materialize. Building roads and bridges can generate quick economic as well as political benefits. However, investing in young children will not bring economic returns until those children grow up and join the workforce. Countries often underinvest in human capital, thereby missing an opportunity to create a virtuous cycle between physical and human capital and growth and poverty reduction. The goal of social progress is the development of personality. One of the tasks is forming the condition for human selfrealization. Human capital is the source of innovation. The correlation between the development of human capital and innovation exist. One of the main tasks of the state is to develop human capital. This task needs creating education policy. Skyba (2018) considers that sustainable economic development, based on the innovative model of development, requires the preparation and attraction of human capital, turning it into a significant factor in social production. When Ukraine ratified the Association Agreement between Ukraine and the EU, it has received a tool and a road sign for internal transformation. Compliance with the requirements of this Treaty will allow Ukraine to become the full member of the EU in the future. This requires the preparation of competitive human capital for the innovative development of the country, and self-realization of an individual. The society, the labour market and the state need qualified specialists. Improving the quality of educational services will raise the issue of implementing institutional changes in the field of education in Ukraine. The higher education system must be a dynamic, flexible, adaptive, effective system capable of adapting and converging in the context of European integration.

Literature Review. Scott (2010) has investigated the Higher Education and the Transformation of Society and concluded that the relationship has become more intense and more direct. Mass higher education systems help to shape their societies more powerfully than the elite systems of the past - not simply quantitatively, because much more people are embraced within these systems, but also qualitatively, because social structures are both more fine-grained and more volatile (and higher education plays more active role in determining not only the division of labor, but also the distribution of cultural capital). Theoretical and methodological aspect of development of pedagogical education in Ukraine researches Lugovyi (1995). Gryshchenko (2014) studies a higher educational institution as an economic entity that carries out a variety of economic activities. Any university has a range of economic relations. They are the costs of the staff (from the rector to the guard), and the costs of the equipment, procurement of materials for educational and scientific purposes, etc. At the same time, they include also the costs for students, the costs for leasing property, the payment for the use of services in the territory of higher educational institutions, etc. Gryshchenko (2014) conducted that such economic actions also create many other additional services that are available products of economic activity of the higher staff educational institution 
staff. From the point of view of an economist, educational activities are the types of human economic activity. As a result, educational products are created (educational, scientific and other services). Curaj, Matei, Pricopie, Salmi $\&$ Scott (2015) propose the unique insights regarding the state of affairs of European higher education research and focus on essential themes in European higher education policies.

The purpose of the article is to present trends in the development of educational institutions, the analysis of the main aspects of the situation in education and the development of recommendations for improving the management and quality of education.

Methodology and research methods. The author uses the universal methods of scientific research (induction and deduction) as well as the method of analysis. The methods of systematization and classification are also applied in the current article. The method of statistical grouping and statistical comparison method are used for the comparison of indicators in the education field in Ukraine with the same indicators in EU countries. National and foreign scientific sources were used to investigate the situation in the sphere of education.

Results. Covering 140 economies, the Global Competitiveness Index 4.0 (GCI 4.0) measures the national competitiveness defined as the set of institutions, policies and factors that determine the level of productivity. They are organized into 12 pillars in the GCI 4.0, reflecting the extent and complexity of the drivers of productivity and the competitiveness of ecosystem. They include: Institutions; Infrastructure; ICT adoption; Macroeconomic stability; Health; Skills; Product market; Labour market; Financial system; Market size; Business dynamism; and Innovation capability. The United Kingdom $(82,0)$, Sweden $(81,7)$ and Denmark $(80,6)$ round out the top ten. 12 pillars in the GCI 4.0, reflecting the extent and complexity of the drivers of productivity and the competitiveness of ecosystem in Ukraine are proposed in fig. 1. (Institutions; Infrastructure; ICT adoption; Macroeconomic stability; Health; Skills; Product market; Labour market; Financial system; Market size; Business dynamism; and Innovation capability). If we compare the indicators of Ukraine with the European countries, we can see that Ukraine was at 83 place (57) by GCI 4.0, and this result is better than in Bosnia and Herzegovina (91 place by GCI 4.0), but worse than in Croatia - 68, Greece - 57, Romania - 52, Bulgaria 51, Hungary 48 and other EU countries.

The innovation ecosystem encompasses all the pillars (Schwab, 2018). Although business dynamism and innovation capability are the factors impacting innovation more directly, they need to be complemented by high levels of human capital (health, education and skills); optimal allocation of skills (labour market functioning); and availability of venture capital and ad-hoc financial products (financial system development). A strong innovation ecosystem also presumes sound infrastructure, ICT readiness and institutions that allow ideas to flow and protect property rights, and a large market size that incentivizes the generation of new ideas. The index component «Innovation capability» (39) is high in Ukraine, but the index component «Health» (72) isn't very high (women's healthy life expectancy is 67 years, while men's - 59).

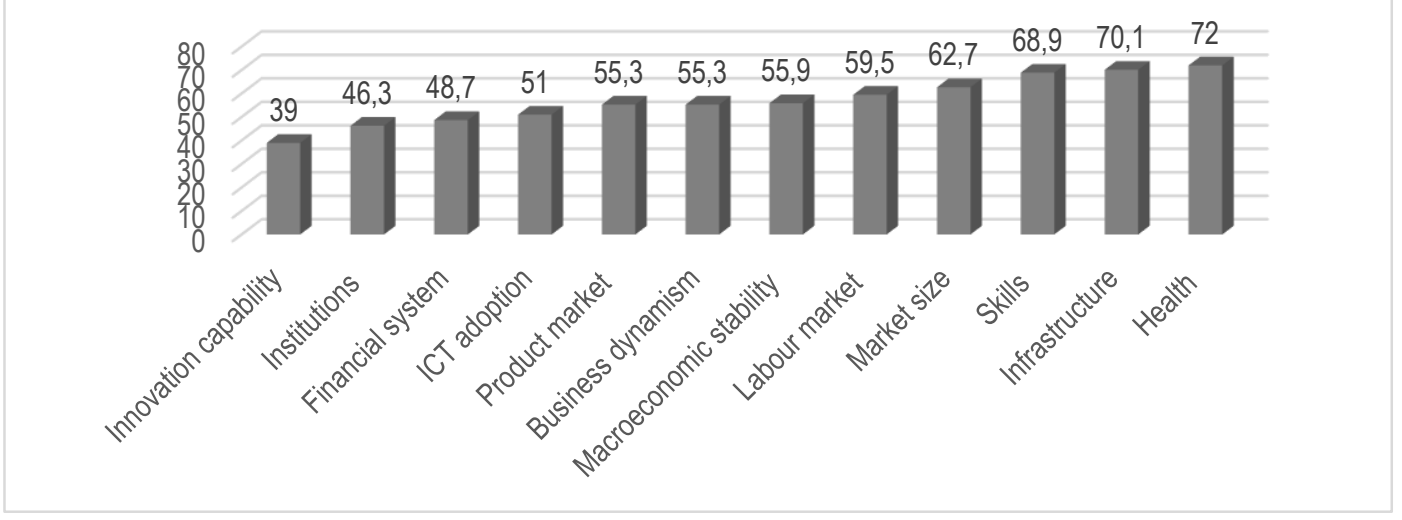

Sources: data of WEF

Fig. 1. Index Component of GCI 4.0 Ukraine, 2018

The EU country with the highest number of healthy life years in 2016 for both women and men became Sweden (73,3 years for women, 73,0 - for men). According to the data of Eurostat in contrast, Latvia had the lowest number of healthy life years for women (54,9 years) and men (52,3 years) in EU. Extreme values can partly explain the way in which the activity limitation is measured in the country, impacting, to some extent, on the results. For better assessment of skills, in experts' opinion, Ukraine (in 2018 - 68,9) should raise the quality of professional training, graduate skills, digital skills among the population, improve the ease of finding skilled employees. A low pupil-teacher ratio suggests that each teacher has to be responsible for a small number of pupils (in Ukraine - 12,8, Poland - 10,5, Sweden - 12,1, Germany - 12,2, Finland - 13,3, United Kingdom - 17,4). In other words, the smaller the pupil/teacher ratio, the higher the relative access of pupils to teachers. It is generally assumed that a low pupil-teacher ratio signifies smaller classes, which enables the teacher to pay more attention to individual students. However, pupil-teacher ratio does not take into account factors which could affect the quality of teaching/learning, such as differences in teachers' qualifications, pedagogical training, experiences and status, teaching methods, teaching materials and variations in classroom conditions. 
«We are living through a fundamental transformation in the way we work» said authors of the report «Workforce of the future: The competing forces shaping 2030». The report draws on the research begun in 2007 by a team from PwC and the James Martin Institute for Science and Civilisation at the Said Business School in Oxford and a specially commissioned survey of 10,000 people in China, India, Germany, the UK and the US. Automation and 'thinking machines' are replacing human tasks, changing the skills that organisations are looking for in their people. The report focuses on what will kickstart your thinking about many possible scenarios that could develop, and how best to prepare for the future. The report experts give the following example: the GDA (Guild for Data Analysts) University in Finland, the first campus university opened by the Guild in Europe. The GDA announced that in 2026 it would be to invest $€ 35 \mathrm{~m}$ in developing the university dedicated to data analytics research and teaching in response to growing demand from its members. The university will initially offer modular courses and accreditation, which will build into three levels of Guild Certification, today's gold standard for data analysis professionals.

The Global Competitiveness Index 4.0 framework is organized into 12 main drivers of productivity, or 'pillars'. It puts a premium on the factors that will grow in significance as 4IR gathering paces: human capital, agility, resilience, and innovation. The 4IR is reshaping the economic landscape by changing the drivers of growth and competitiveness. It is no longer possible to rely solely on efficiency and cost-cutting for economic success: innovation, flexibility and adaptation to the changes are becoming the key ingredients. When the changes are constant, then economies that can adopt new ideas, methods or products more quickly will gain an edge. Therefore, embracing opportunities and leveraging innovations can accelerate growth and development for every economy. In 2018 the top by the pillar «innovation capability» became Germany $(87,5)$, the United States $(86,5)$ and Switzerland $(82,1)$. Ukraine was on the $58(39,0)$ place by the pillar «innovation capability», this indicator proves that Ukraine is not using its potential sufficiently.

We should remind that in June 1999, the Ministers of 29 European countries met in Bologna to sign the "Declaration", which formally gave rise to the Bologna Process. Its aim was to make our countries' very different higher education and training systems more compatible, in order to facilitate collaboration, mobility, international understanding and the continuous improvement of the quality of our higher education provision. It is well known that the Ministers, who are in charge of Higher Education in the EHEA countries, periodically meet to take stock and to determine future actions. At their recent Paris Conference, in May 2018, they adopted the 'Communiqué', which fixes present priorities and looks beyond towards more ambitious European Higher Education Area in and after 2020. Therefore, the experience of European countries is very important for the educational reform.

At the moment when Europe is facing important societal challenges - ranging from unemployment and social inequality to migration-related issues and a rise in political polarisation, radicalisation and violent extremism higher education can and must play a decisive role in providing solutions to these issues. National development should be measured not only by income per capita, as it was in practice for a long before, but also by education achievements. All regions and human development groups have made substantial progress. The global HDI value in 2017 showed 0,728, that is, it was up about 21,7 percent from 0,598 in 1990. People all over the world are living longer, becoming more educated and have greater livelihood opportunities.

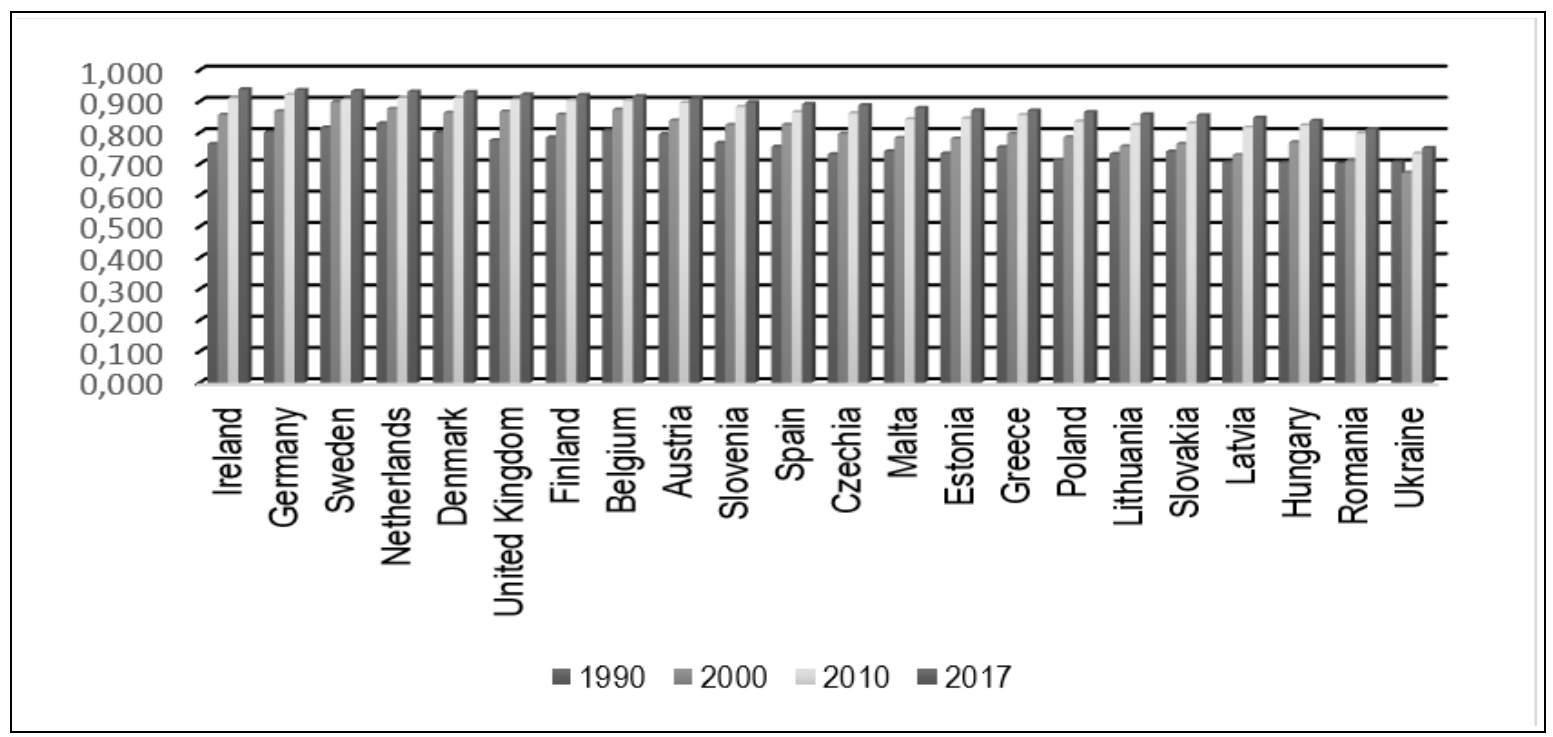

Sources: data of UNDP

Fig. 2. Human Development Index, 1990-2017 
The average lifespan is seven years longer than it was in 1990, and more than 130 countries have universal enrolment in primary education. The top five countries in the global HDI ranking are Norway $(0,95)$, Switzerland $(0,94)$, Australia $(0,94)$, Ireland $(0,94)$ and Germany $(0,94)$. Ukraine had 0,75 in 2017 and was in the global HDI ranking on the 88 place $(2016$ - 90), Latvia - on the 41 place $(2016-43)$. Support reform in education gives the impressive result in Poland (the 33 place in 2017). Between 2012 and 2017, the largest increases in HDI rank took place for Ireland, which moved up 13 places. Between 1990 and 2017, the largest increases in HDI rank concerning EU were for Ireland $(0,77)$, the Czech Republic $(0,72)$, Poland $(0,72)$. As for Ukraine it was 0,23.

The HCI measures the amount of human capital that a child born today can expect to attain by the age of 18 . It conveys the productivity of the next generation of workers compared to the benchmark of complete education and full health. It is made up of five indicators: the probability of survival to the age of five, the child's expected years of schooling, harmonized test scores as a measure of quality of learning, adult survival rate (fraction of 15years old that will survive to the age of 60), and the proportion of children who are not stunted.

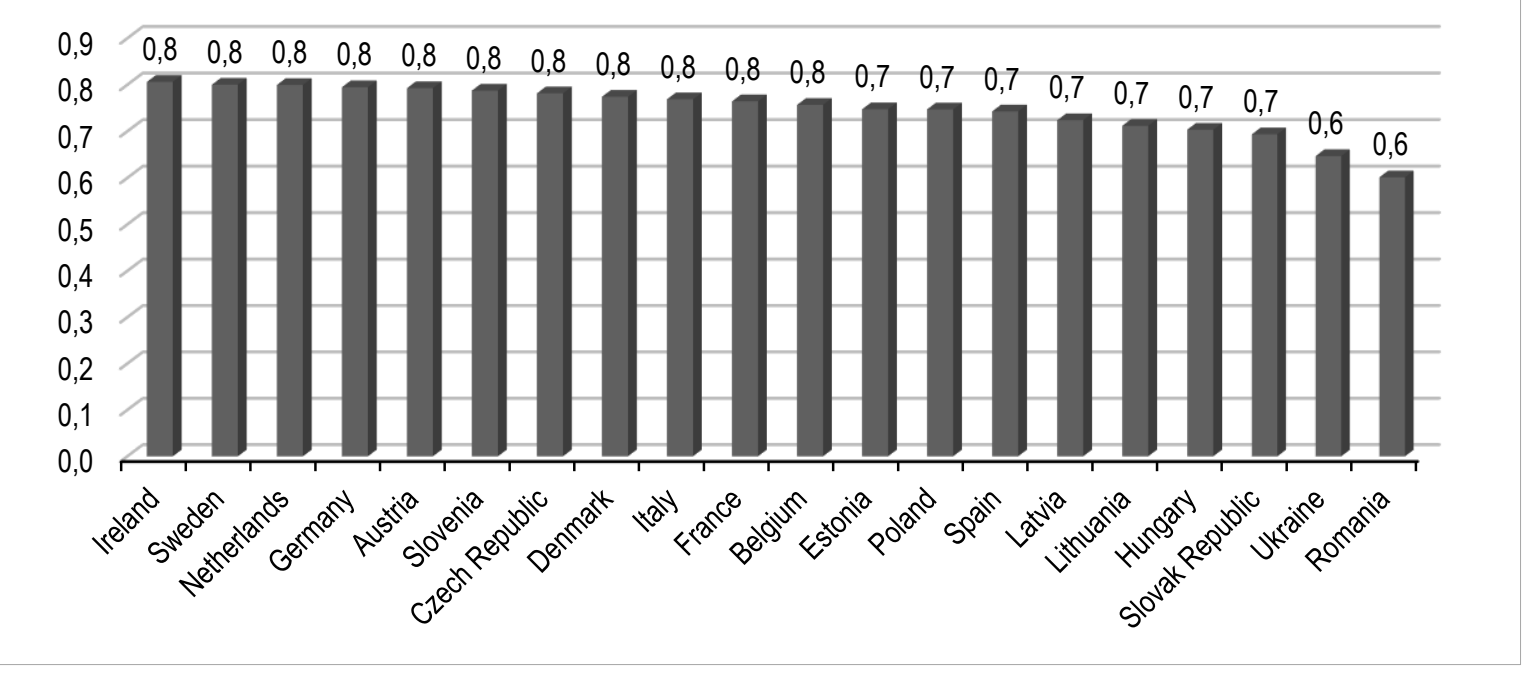

Sources: data of World bank

Fig. 3. Human capital index, 2018

The completeness of this indicator is questionable. The research results of PISA-2018 (at the end of 2019) can be very revealing. Ukraine had $50(0,65)$ place in the rank of The Human Capital Index $(2018)$. It was better than Romania - 67, but worse than Poland - 30, Sweden - 8. The children born in Ukraine today will be $65 \%$ more productive, as they could be, when they grow up, if they enjoyed complete education and full health (in Romania $60 \%$, in Poland $-75 \%$, the Czech Republic - 80\%, Sweden - $85 \%$ ), according to the World Bank's Human Capital Index (HCI). In opinion of some experts, Ukraine has the human capital of not high quality, which has uncompetitive character. Human capital is unable to work, think and act in a modern, innovative way. That is why the human capital formation system needs essential modernization.

It should be noted that the insufficient education quality is caused by insufficient funding, low salaries of teachers, inadequate logistical support for schools, bureaucratization of the education management system, and the outdated content of education and teaching methods. It is also proved by international experts.

The current situation of the education in Ukraine is characterized by the imperfection of the institutional environment and steady trend towards reducing the number of educational institutions, associations of pre-school educational institutions, general educational institutions, vocational schools, higher educational establishments. The situation in secondary schools of Ukraine is characterized (by the source of the Ministry of Education and Science) by the following tendency: the total number of institutions of general secondary education is constantly decreasing. It is a long-term tendency. The number of institutions decreased from 21,8 thousand in 1990 to 15,5 in 2018 (by 6,3 thousand or 28,9\%). The load per teacher has not been exceeding 10 pupils on average since 2006 (in 1990 - 13 pupils, in 2018 - 9 pupils).

According to the data of the State Statistics Service of Ukraine: in 2017 the combined expenditures of the consolidated budget for education amounted to $6 \%$ of GDP, while in $2010-7,4 \%$ of GDP, in $2013-7,3 \%$ of GDP. Since 2017, the share of spending on general secondary education on the volume of all educational expenditures has increased. So, if during 2014-2016 the share of expenditures was in the range of 42,4-43,7\%, then in 2017 it grew up to 47,4\%. In 2016 spending on general secondary education was levelled out, and in 2017 exceeded inflation (149,2 \% versus 114,4 \%, respectively). In 2017 the average monthly wage in the education sector grew: its growth rate was $155,4 \%$ in comparison with the previous year. The average monthly wage increase in the general secondary education was the highest, it was $161,1 \%$, which is significantly higher than the average 
rate of growth in the economy. It should be noted that 7,6 million full-time employees are employed in all the spheres of the Ukrainian economy, almost $1 / 5$ is employed in the field of education. The average monthly wage paid to the staff member in the field of education in Ukraine does not exceed the average monthly salary, accrued to the full-time employee in the Ukrainian economy.

According to the data presented on the official site of the statistics of Poland, the average monthly wages in the field of education in Poland is almost equal to the wages in the country's economy as a whole. According to the data presented on the official site of the statistics of Sweden, the monthly wages in Sweden exceed the average monthly wages in the economy. In Ukraine, in October 2018, the average monthly wages accrued to the staff member in the field of education was lower by $23,7 \%$ of the average monthly salary of the full-time employee in the economy of Ukraine (in January-October 2018, by 20,1\%, in 2017 less by 17,6 \%, in $2016-25,3 \%$ ).

Table 1 shows the dynamics of the key indicators in the field of education. The total number of Higher educational institutions is constantly decreasing (33,4\% from 2000 to 2018). The number of HEIs increased from 657 (in 2016) to 661 (in 2017), but decreased to 652 (in 2018).

Table 1

Dynamics of key indicators in the field of education

\begin{tabular}{|c|c|c|c|c|c|c|c|c|}
\hline \multirow[b]{3}{*}{ 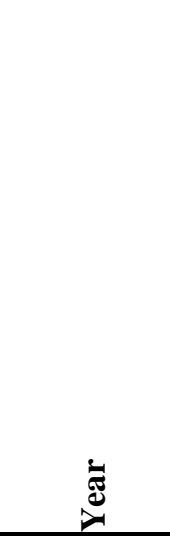 } & \multicolumn{4}{|c|}{$\begin{array}{l}\text { Professional technical } \\
\text { educational institutions }\end{array}$} & \multicolumn{4}{|c|}{ Higher educational institutions } \\
\hline & \multirow{2}{*}{ 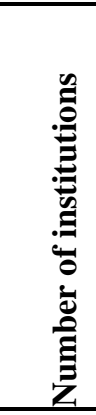 } & \multirow[b]{2}{*}{ 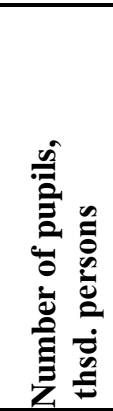 } & \multirow[b]{2}{*}{ 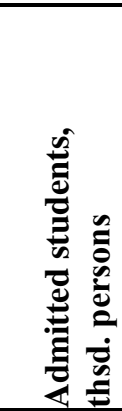 } & \multirow{2}{*}{ 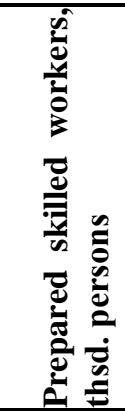 } & \multicolumn{2}{|c|}{$\begin{array}{l}\text { Number } \\
\text { universities }\end{array}$} & \multicolumn{2}{|c|}{$\begin{array}{l}\text { Number of students in } \\
\text { higher educational } \\
\text { establishments, thsd. } \\
\text { persons }\end{array}$} \\
\hline & & & & & 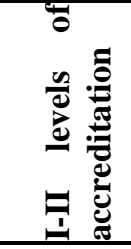 & 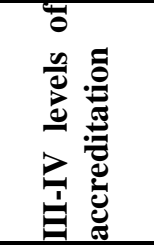 & 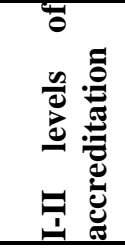 & 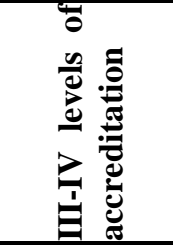 \\
\hline 2000 & 970 & 524,6 & 307,3 & 266,8 & 664 & 315 & 528 & 1402,9 \\
\hline 2010 & 976 & 433,5 & 282,9 & 247,4 & 505 & 349 & 361,5 & 2129,8 \\
\hline 2016 & 787 & 285,8 & 157,9 & 152,8 & 370 & 287 & 217,3 & 1369,4 \\
\hline 2017 & 756 & 269,4 & 146,9 & 141,3 & 372 & 289 & 208,6 & 1330 \\
\hline 2018 & 736 & 255 & 136,6 & 133,5 & 370 & 282 & 199,9 & 1322,3 \\
\hline $\begin{array}{l}2000-2018, \\
\%\end{array}$ & 24,12 & 51,39 & 55,55 & 49,96 & 44,28 & 10,48 & 62,14 & 5,75 \\
\hline $\begin{array}{l}2000-2018, \\
\%\end{array}$ & & & & & 33,40 & & 21,17 & \\
\hline
\end{tabular}

Sources: the State Statistics Service of Ukraine, the Ministry of Education and Science of Ukraine

The total number of professional technical educational institutions is constantly decreasing $(24,12 \%$ from 2000 to 2018). The number of students in professional technical educational institutions decreased (51,39\% from 2000 to 2018). The low level of education and qualifications does not help to get high wages in the future. Therefore, children do not want to enter professional technical educational institutions.

Each year, the number of young people who go to both secondary and higher education abroad (Poland, Slovakia, Germany, Italy, the USA, UK, etc.) is increasing. The process of migration of Ukrainian students to Poland has continued since 2018. According to the data provided by the Site Center of Society Studies, an active marketing campaign in Poland, the Czech Republic and other countries have led to the growth dynamics from 2009 to 2016 and amounted to $176 \%$. The growth of Ukrainian students in Russian universities has slowed down somewhat, their number grew slightly more than a thousand. Such growth is not typical and differs from previous years before Russian aggression started. Therefore, obviously, it is mostly the result of involuntary migration of Ukrainians of admission age from temporarily un-controlled territories of Donetsk and Luhansk regions to Russia. Comparing the last two years, we can see that the growth is almost $20 \%$ or 10,934 people. Moreover, 2/3 of this increase was made up by Ukrainians studying at Polish universities. They showed the most rapid increase, both in absolute and relative terms, from 22,833 to 30,041 persons (almost $32 \%$ ).

Conclusions. The systematization of literary sources and approaches to solving the problem of education management proves that education becomes important in terms of the formation and creative potential and 
development of innovation human potential. The current situation of the education in Ukraine is characterized by the imperfection of the institutional environment and steady trend towards reducing the number of educational institutions, associations of pre-school educational institutions, general educational institutions, vocational schools, higher educational institutions. The main problems in the sphere of education that require systemic, longterm, and complex measures at the central and local level are: the incompleteness of the decentralization in the sphere of education, the imperfection of the institutional and legal environment in the sphere of education, the institutional weakness of local self-government bodies and the united territorial communities on the regulation of issues in the field of education. In order to improve the quality of education, including the quality of general secondary education, the growth of innovative potential, the quality of human and intellectual capital it is generally advisable to formulate a number of recommendations. Taking into account the general long-term tendency to reduce the population, the processes of internal and external migration, etc. in the regional development strategies and in the strategies for the development of the united territorial communities (amalgamated hromadas), we single out the following principal directions for the improvement of education policy tools in the context of sustainable economic development: to predict the need for specialists with higher education in pedagogical specialties in rural areas or urban-type settlements; to formulate, at the cost of the municipal budget, contracted funds of enterprises, institutions and organizations, irrespective of the forms of ownership, as well as the funds of the population, and other sources, in the form of general education institution of communal ownership form of funding of compulsory education; to exercise control over the use of funds of this fund for its intended purpose; consider amending the decisions on local budgets to increase the amount of budget allocations and the wage fund needed to establish the allowance for teaching staff for high achievements in work, for performing particularly important work or for complexity, work intensity, etc.; implement training programs, trainings and workshops for village heads to ensure and provide key management directors with cutting-edge managerial competencies, armament with their innovative approaches to managing educational institutions and their affiliates; to improve and approve procedures for recognizing various forms of professional development in the system of professional development of teaching staff.

\section{References:}

1. «Bologna beyond 2020: Fundamental values of the EHEA», [Online], available at: http://bolognaprocess2019.it/

2. Verhovna Rada Ukrai'ny (2010), Byudzhetnyy kodeks Ukrayiny, Zakon, [Online], available at: http://zakon.rada.gov.ua/laws/show/2145-19 http://zakon.rada.gov.ua/laws/show/2456-17

3. Curaj, A., Matei, L., Pricopie, R., Salmi, J. and other (2015), The European Higher Education Area: Between critical reflections and future policies, Springer International Publishing, Heilderberg, New York, London.

4. Gryschenko, I.M. (2014), Profesiyna osvita v systemi ekonomichnykh doslidzhen, Gramota, Kyiv, Ukrainian.

5. Gryshchenko, I.M. (2016), «Faktory pidvyshchennya efektyvnosti navchal'noyi diyal'nosti vyshchykh navchal'nykh zakladiv Ukrayiny», Aktualni problemy ekonomiky, Vol. 3, 134-141, Ukrainian.

6. «Indeksy ta pokaznyky lyudskoho rozvytku 2018 Statystychne onovlennya», [Online], available at: http://hdr.undp.org/sites/default/files/2018_human_development_statistical_update.pdf

7. «Informatsiynyy byuleten» [News bulletin], [Online], available at: http://iea.gov.ua/wpcontent/uploads/2018/04/BYULETEN\%60-materialna-baza-ZNZ-17-18.pdf

8. Human development index (1990-2017), [Online], available at: http://hdr.undp.org/en/content/human-developmentindex-hdi

9. «The Human Capital Index» (2018), [Online], available at: https://datacatalog.worldbank.org/dataset/human-capital-index

10. Kim, J.Y. (2018), Vidminnosti u rozvytku lyuds'koho kapitalu: diyi uryadu shchodo investuvannya $v$ lyudey zovnishnya polityka, [Online], available at: https://www.foreignaffairs.com/articles /2018-06-14/human-capital-gap

11. Kremen, V.G., Lugovyy, V.I., Gurzhii, A.M. and Savchenko, O.Ya. (2017), Natsional'na dopovid' pro stan ta perspektyvy rozvytku osvity $v$ Ukrayini, Pedahohichna dumka, Kyiv.

12. Lugovyi, V.I. (1995), Tendentsiyi rozvytku pedahohichnoyi osvity v Ukrayini (teoretyko-metodolohichnyy aspekt), Institute of Pedagogics of the Academy of Pedagogical Sciences of Ukraine, Kyiv.

13. Minfin Ukrayin (2018), Profspilky pratsivnykiv osvity i nauky Ukrayiny vid 05.09.2018 № 02-5/496 shchodo pidvyshchennya rozmiriv posadovykh okladiv ta stavok zarobitnoyi platy pedahohichnykh ta naukovopedahohichnykh pratsivnykiv zakladiv osvity, Lyst, № 07010-07-10/23787 u., [Online], available at: https://pon.org.ua/novyny/6619-mnfn-pdvischennya-zarplat-osvtyanam-rozbalansuye-mscev-byudzheti.html

14. «Zvit pro svitovyy rozvytok 2019: Zmina kharakteru», [Online], available at: robotyhttps://openknowledge.worldbank.org/handle/10986/30435

15. «Sayt derzhavnoyi sluzhby statystyky Ukrayiny», [Online], available at: Retrieved from. www.ukrstat.gov.ua

16. «Sayt detsentralizatsiya», [Online], available at: https://decentralization.gov.ua/

17. «Sayt Tsentr doslidzhen suspilstva», [Online], available at: https://cedos.org.ua

18. Scott, P. (2010), Higher Education and the Transformation of Society, [Online], available at: from.https://www.researchgate.net/profile/Peter_Scott11/publication/255968770_Higher_Education_and_the_Tran sformation_of_Society/links/59f218dea6fdcc1dc7bb1084/Higher-Education-and-the-Transfor-mationofSociety.pdf

19. Skyba, M.V. (2018), «Osnovni tendentsiyi vyshchoyi osvity v Ukrayini v konteksti suchasnykh vyklykiv yevropeyskoyi intehratsiyi»,Mizhnarodne pidpryyemnytstvo. International Entrepreneurship, No. 2 (4), pp. $43-54$. 
20. Skyba, M.V. (2018), Key directions for improving the institutional environment for development of human capital in the context of the growth of the quality of educational services provision, [Online], available at: https://er.knutd.edu.ua/bitstream/123456789/10186/1/EOEMIR2018_P099-107.pdf

21. Schwab, K. (2018), The Global Competitiveness Report 2018, [Online], available at: http://www3.weforum.org/docs/GCR2018/05FullReport/TheGlobalCompetitivenessReport2018.pdf

22. «Statystyka saytu Polshchi», [Online], available at: http://stat.gov.pl/en/

23. «Statystyka saytu Shvetsiyi», [Online], https://www.scb.se/en/

24. "Workforce of the future: The competing forces shaping 2030», [Online], available at: https://www.pwc.com/gx/en/services/people-organisation/workforce-of-the-future/workforce-of-the-future-thecompeting-forces-shaping-2030-pwc.pdf

25. Verhovna Rada Ukrai'ny (2017), Pro vyshchu osvitu, Zakon, N 2657-VIII, [Online], available at: http://zakon.rada.gov.ua/laws/show/1556-18

26. Verhovna Rada Ukrai'ny (2018), Pro osvitu, Zakon, N 2661-VIII, [Online], available at: http://zakon.rada.gov.ua/laws/show/2145-19

Скиба Марина Валеріївна - кандидат наук з державного управління, доцент Київського університету технології та дизайну.

Наукові інтереси:

- публічне управління та адміністрування;

- інституційне забезпечення сталого розвитку, освітня політика.

Стаття надійшла до редакції 25.04.2019. 